\title{
Pathomorphism of timb Major Vessels in Experimental Atherogenic inflammation. The Role of Adventitial Intimal Relations (Review)
}

DOI: $10,17691 /$ stm2017.9.3.20

Received November 28, 2016

A.K. Kirichenko, MD, DSc, Professor, Pathological Anatomy Department;

N.N. Patlataya, PhD, MD, Teaching Assistant, Department of Operative Surgery and Topographic Anatomy;

A.F. Sharkova, Student, Pathological Anatomy Department;

A.A. Pevnev, Student, Department of Operative Surgery and Topographic Anatomy;

K.V. Kontorey, Student, Department of Operative Surgery and Topographic Anatomy;

O.V. Shapovalova, Student, Department of Operative Surgery and Topographic Anatomy;

M.E. Gorban, Student, Department of Operative Surgery and Topographic Anatomy;

I.N. Bolshakov, MD, DSc, Professor, Department of Operative Surgery and Topographic Anatomy

Krasnoyarsk State Medical University named after Prof. V.F. Voino-Yasenetsky, 1 Partizana Zheleznyaka St., Krasnoyarsk, 660022, Russian Federation

The review considers the problems of pathological destruction of a vascular wall at early signs of atherogenic inflammation of major arteries in hyperlipidemia in relation to modern technologies of local angioplasty. It has shown the role of molecular markers in atherogenic inflammation development and progression in intima and subintimal space. The emphasis is laid on modern genetically engineered and biopolymer technologies for vascular wall repair, the significance of adventitial and para-adventitial arterial layers in atherogenic inflammation, the formation of a therapeutic angiogenesis effect when using modern methods of adventitia bioengineering.

Key words: atherogenic inflammation; atherogenesis markers; vascular wall; therapeutic angiogenesis; morphological angioplasty; genetically engineered drugs; biodegradable polysaccharide structures; vascular adventitia engineering.

The success in combating such diseases as infarction, stroke, lower limb chronic ischemia depends mainly on solving the problems of atherosclerosis diagnosis, management and prevention. It is significant that effective treatment of patients with lower limb chronic ischemia and inflammatory process regression in arteries is possible subject to an early detection and treatment of the disease [1-3]. Lower limb peripheral arterial occlusive disease is an important and very frequent manifestation of systemic atherosclerosis resulting in a significant decrease in patients' mobility, deterioration in life quality, and associated with a high risk of cardiovascular incidence and mortality rate [4, $5]$, its incidence growing steadily [6, 7]. Moreover, the development of lower limb critical ischemia indicating nearly complete circulatory decompensation occurs as frequently as 400-1,000 per a million of population a year, or in 15-20\% patients with lower limb peripheral arterial occlusive disease [8, 9]. The expected mortality of patients with critical ischemia is increasing from $25 \%$ within the first year of the syndrome development to $60-70 \%$ during the next $3-5$ years. The indications for high, i.e. above the knee joint, amputation reach 52$95 \%$ within 3 years, total mortality rate during the period increasing from $10-40$ up to $71 \%$ [10]. Experimental practice shows [11] that a chronic cholesterol diet in experimental rats and rabbits is an adequate model to form the early signs of atherogenic inflammation in limb major vessel walls. The use of pure cholesterol as a part of a diet for outbred rats for 60 days results in high hyperlipidemia increasing the level of total lipid fractions by 2.5 times, triglycerides - twice as high, unesterified fatty acids - by 26 times. The use of a cholesterol diet in chinchilla rabbits within $80-110$ days provides the increase of triglycerides by 1.5-2.5 times, cholesterol level - by 30-90 times, low-density lipoprotein (LDL) fractions - by 29-56 times and higher; the fraction of very low-density lipoproteins (VLDL) - by 2.5-5.0 times in blood plasma forming a very high atherogenicity coefficient.

High hyperlipidemia in animals corresponds to a high level of lipid fractions in vascular wall tissues of major arteries and exceeds the level of total lipids in femoral arteries thrice, and triglycerides - by 2.5 times forming the accumulation of xanthoma cells in the intima. Atherogenic inflammation in experimental animals causes a marked intimal edema in a form of disintegrated fiber component of internal elastic membrane, the

For contacts: Igor N. Bolshakov, e-mail: bol.bol@mail.ru 
occurrence of xanthoma cells, proliferation of smooth muscle cells subintimally and in media, with its irregular thickening and the formation of a typical lipid ("soft") plaque covered by a fibrous membrane resulting in a reduced vascular lumen diameter $[12,13]$.

Cholesterol feeding of animals, rabbits in particular, regularly leads, in addition to hypercholesteremia, to cholesterol deposits in tissues, and to the utmost in the internal membrane of major arteries. Vascular lipidosis develops, it being observed usually in a 3-4-month experimental period. Marked atherogenesis has revealed on average by a feeding day 90-100, though it can become evident within a significantly shorter period of time. Vascular pathomorphism in atherogenic inflammation involves whitish or slightly yellowish spots or stripes, usually a bit rising over the surface, formed on the intima of major vessels. When cerasin red stained, they are well red dyed, it presenting a bright picture of lipid inclusions against a white intima background. Lipoid accumulations are primarily in the apical part of the ascending aorta above the valves, as well as in the aortal arch and in the orifice area of major vessels coming from the aorta [14-17].

Endothelial dysfunction manifests itself as increased permeability and adhesion, as well as enhanced secretion of pro-coagulants and vasoconstrictors. The most significant damaging factor is the increase in LDL level [18-20]. The first stages of pathomorphism development of atherogenic inflammation are characterized by gradual lipid accumulation: first, inside, and then extracellularly with the formation of a lipid spot/ stripe followed by a new atherosclerotic plaque [21, 22]. Such microscopic picture in vessels is accompanied by signal molecular transduction of markers starting with the oxidation of LDLs and VLDLs, therefore, the occurrence of weak angiogenic structures able to determine a weak immune response. Electrostatic relations of oxidized LDL as a part of apoprotein B form antigenic determinants to interact with immune cells.

An important trigger mechanism in atherogenic inflammation development is the initiation of presentation of antigenic epitopes to immune cells ( $A$ and $T$ cells) in the major vessel intima, the circulation of oxidized LDL in vessels [23, 24]. A level of specific antibodies to oxidized LDL indicates primarily the activity of atherogenic inflammation development [25]. However, it may happen that the marker also signals the atherosclerotic damage degree [26]. Thus, oxidized LDLs fulfil the role of neoantigens initiating inflammatory reactions, which lead to atherosclerosis progression, and the antibodies to such LDL can be considered an independent predictor of atherosclerotic disease progression and a marker of LDL oxidation [27].

Oxidant system activation in the presence of hyperlipidemia forms the accumulation of monocyclic endoperoxides with metabolisation into aldehyde compounds and Schiff's bases. It is of importance that the process activates in the subintimal space of an arterial wall, where LDLs are oxidized. Oxygen metabolites of activated macrophages captured a large mass of LDL, $\mathrm{T}$ lymphocytes concentrate in an intima, trigger lipid oxidation inside and outside the cells, active absorption of oxidized forms forming a great number of foam (vacuolated) cells [28, 29]. The overload of cells by lipid oxidized forms an apoptotic cascade with macrophage damage. A large number of cholesterol crystals in the subintimal space outside the cells clearly reveal the picture of atherogenic inflammation known to morphologists.

Proliferation of smooth muscle cells in the middle layer of a vessel with destabilization of their orientation, trafficking to intima space from a middle layer gives to the inflammatory process the stability of a future atherogenic construction in a form of connective tissue proteins (collagens, proteoglycans, elastins) secreted to the extracellular space. This is a future fibrous frame of an atherogenic product. It will separate a lipid nucleus from a blood flow lumen. The stimulation of vascular endothelial growth factor (VEGF) by intimal cells will provide the proliferation of vascular endothelium, its migration to atheromatous plaque location. New formation of microvessels in intima will increase the volume of an atherogenic product, enhance the inflow of foam cells and their destruction. The accumulation of oxidized LDL in the subendothelial space enhances vascular endothelial dysfunction increasing the adhesion of endothelial cells, and forming lipid and cellular leakages.

Active escape of blood stream by monocytes, and the activation of receptor phenotype under endothelium many times increase the capture of a lipid mass [30]. Impaired expression balance of pro-atherogenic (proinflammatory) and anti-atherogenic (anti-inflammatory) cell markers if hyperlipidemia conditions are preserved stabilize destruction in subendothelial space. The expression of blood residual cell receptors under vascular endothelium and of vascular endothelium itself, namely: endothelin-1 [31-35], caveolins-1, -2 , and -3 $[36,37]$, selectins $P(C D 62 P), E(C D 62 E), L(C D 62 L)$, and antibodies to them on vascular endothelium, lymphocytes and platelets [38-40], intercellular adhesion molecule-1 (ICAM-1) marker [41-43], vascular cell adhesion molecule-1 (VCAM-1) marker [44-47], monocyte chemotactic protein (MCP-1) [48-50], macrophage colony-stimulating factor (MCSF) [51-57], pleiotropic cytokine (TNF-a) [58-64], C-reactive protein (CRP) [65-70], platelet derived growth factor (PDGF) [71-77], interleukin family in atherosclerosis [78-81] create a picture of multicellular destruction involving all layers of a major vessel including adventitial space [82].

A level of pro-inflammatory cytokines circulating in blood plasma correlates with a cytokine level in an atherogenic plaque [83]. In addition, multifunctional interferon activating macrophages (IFN- $\mathrm{Y}$ ), as well as IL-6, IL-12, and IL-15, tumor necrosis factor (TNF- $\alpha$ ) are expressed highly by NK and $\mathrm{T}$ cells in a soft 
plaque compared to the intact artery exceeding the activity levels of anti-inflammatory cytokines such as IL-4, IL-10 [84-86]. Among cytokines, IFN-y is a key factor in atherosclerosis pathogenesis, since the marker plays a multifunctional role in the development of both early (factors VCAM-1, ICAM-1, cytokines, chemokines, class I and II antigens of expression induction of major histocompatibility complex (MHCs) on macrophages, T lymphocytes, NK cells) and late stages of atherogenic inflammation including the pool formation of macrophages saturated with oxidized LDL forms, cholesterol accumulation in an atheromatous plaque with cytokine activation, NO-synthase of monocyte chemoattractant protein (MCP-1), increased synthesis of proteins of metalloproteinases [87, 88].

The deficiency of a gene controlling IFN-y synthesis in experimental atherogenesis results in the reduction of pathomorphological disturbances in a vessel wall, and restenosis [89]. Mass capture of oxidized LDL by macrophages is provided mainly by the expression of category A (SR-A) and B (SR-B1, CD36) scavengerreceptors [90-92]. Any artificial external intervention in the pathological molecular cellular cascade for the purpose of therapy is oriented on a break in interrelated processes of progressive atherogenic inflammation. Such external interferences are known as treatment methods aimed primarily at the consequences of the process: surgical reconstructive vascular operations [93-99], physiotherapeutic interventions [1, 100, 101]. The introduction of genetic engineering constructions [102] in ischemic tissues, implantation of polymer polysaccharide constructions in perivascular cases for major arteries [103-107] aims at local reconstruction of a vascular wall. It should be mentioned that the use of only genetic engineering constructions administered intravenously or directly in limb ischemic tissues synthetic analogues of prostaglandins: lloprost [108110], prostanoids; registered in Russia Alprostan, Vazaprostan (PGE-1-alprostadil) [102, 111], VEGF165 gene [112, 113], Neovasculgen [114-122] — are meant for rearrangement of subendothelial, middle and adventitial layers of major and small limb arterial vessels. Such rearrangement concerns the activity of vascular endothelial proliferation, its translocation in interstitial tissue with the formation of a great number of new additional microvessels (therapeutic angiogenesis) that by itself is the objective for researchers.

A modern trend in atherogenic inflammation regulation includes the methods of controlling the progressive atherosclerosis degree, the methods aiming at applying the technologies counterbalancing the effect of pro-atherogenic molecules both at the level of forming antigen-antibody complexes, and also at the level of genetic engineering constructions blocking the operation of genes responsible for the synthesis of pro-atherogenic proteins such as VCAM-1, ICAM-1, TNF- $\alpha$, GM-CSF, M-CSF, G-CSF, or the administration of antagonists of cytokines or their receptors, e.g., to IL-1 or to IL-1R (IL-
1Ra) [78, 123]. The control of atherogenic inflammation degree by regulating the expression of pro-atherogenic markers results in the development of new preventive and treatment modalities for atherosclerosis [124].

Constructions based on liquid polysaccharides (sulfated forms of chitosan, chitosan ascorbate, chitosan hydrochloride, alginate) when introduced in fascial compartments of neurovascular bundles $[12,13]$ create an effect of therapeutic angiogenesis. Local administration of chitosan copolymer containing endothelial cells of the umbilical vein to the mice with experimental lower limb ischemia within 2 weeks clearly formed a new vascular net in the arterial trunk [125]. Endothelial cells reprogrammed from embryonic stem cells encapsulated in chitosan hydrogel in combination with VEGF, when administered locally in animals with lower limb ischemia model, resulted in neovascularization through the mechanisms of vasculogenesis and angiogenesis, with effective blood flow recovery in ischemic tissues [126]. In addition to therapeutic angiogenesis effect, chitosan copolymers create a direct contact with an atherogenic construction in the subendothelial space of major arteries due to electrostatic, concentration and affine relations and, more precisely, with cholesterol-containing molecules of both: a lipid nucleus of soft plaques, and also foam cells of an intimal layer.

Special attention should be paid to the adventitia in tissue engineering of major vessels [127, 128]. It has been clearly shown [129] that hypercholesterolemia remodels an intimal vascular layer and induces endothelial dysfunction. Hyperoxidation in an adventitial layer of a vessel using NADPH-oxidase induces an inflammatory response of a vessel with the expression of pro-atherogenic markers (MCP-1, IL-6) in the middle and endothelial layers of a major artery, stimulates the translation of myofibroblasts into an intimal layer of the artery [130, 131]. The use of apocynin, an inhibitor of NADPH oxidase on myofibroblasts, and probably, on macrophages results in blocking neointimal growth and endothelial dysfunction [132]. Thus, adventitia is no less important layer of a vascular wall actively involved in atherogenic inflammation associated with the middle and intimal layers of major vessels.

Similar changes resemble a morphological picture in nonspecific aorta-arteritis or Takayasu disease. However, it is characteristic that in Takayasu disease a granulomatous inflammatory process starts initially in adventitia and internal media layers; microscopic study of granulomas in adventitia reveals the accumulations of lymphocytes, plasma, and reticular cells. Later on, there is granuloma fibrosis, hardening and rupture of media, endothelial proliferation. Immunogenetic basis of such inflammation is presented by markers-antigens $\mathrm{HLA}-\mathrm{A}_{10}$, HLA-B ${ }_{5}$, HLA-Bw52, HLA-DR2. The lumen narrowing or the occlusion of aorta, its large branches in proximal regions of upper and lower limbs is not related to atherosclerosis and the picture of hypercholesterolemia. 
The concept of morphological rearrangement of qualitative and quantitative characteristics of internal layers of the vessel affected by atherogenic inflammation suggested by the authors consists in an artificial arrangement of such ingredients in the perivascular space, which are able to have an effect on intimal and middle layers leading to the normalization of both cellular and intercellular structure, lipid spectrum of a vascular wall, but also macroscopic characteristics of a vessel, such as the thickness of intima, media, the diameter of major arteries. It is important [82] that adventitial and para-adventitial layers take their primary place in treatment intervention and drug delivery in order to solve the problems of controlling an inflammatory process including atherogenesis. Therefore, the attempts to control cell-tissue compartment in an adventitial layer in atherogenesis are sensible, if the purpose is to "develop" the main events of atherogenic inflammation, and its reduction in adventitial and para-adventitial areas, rather than in the zone of internal layers of a major vessel, especially in an early inflammatory process. It has been proved demonstratively [133] that about $20 \%$ cells of adventitial population of the mouse aortic root are composed of the precursors of smooth muscle cells capable of forming atherosclerotic impairment of the middle layer of a vessel under hyperlipidemia. The precursor cells applied on a decellularized venous wall result in their migration via a vascular wall with partial formation of a neointimal layer. In recent years, vascular adventitia is considered as a key component of vascular response to damage, the engineering of which is able to regulate the proliferation of smooth muscle cells of the middle and endothelial vascular layers that are of importance in atherogenic inflammation development [134]. Experimental data indicate the presence of the relationship between vasa vasorum and neointima formation after experimental damage [129]. The relationship is proved by a number of studies on vascular impairment modeling and minimally invasive arrangement of biopolymer particles containing allogenic endothelial cells near to a major vessel [135]. Tissue engineering in the adventitia area in open or closed surgeries in experimental models inhibit intima thickening, restenosis formation, negative remodeling [136-138].

The technologies to obtain a therapeutic angiogenesis effect are one of the promising methods used to treat chronic (critical) lower limb ischemia in patients, who are not candidates for surgical or endovascular revascularization. A concept of therapeutic angiogenesis implies creating in ischemic tissues such concentration of angiogenic growth factors, which will enable to achieve an effective stimulation of natural angiogenesis. For this purpose, in clinical practice there can be used preparations of recombinant angiogenic growth factors or their genes, as well as stem and progenitor cells $[139,140]$. Angiogenesis is a complex process including a series of events occurring in strict sequence. These processes involve endothelial cells and pericapillary cells [141], which are located in arterioles, capillaries, and postcapillary venules. Under the influence of angiogenic stimuli, which include hypoxia, ischemia, mechanical strain and inflammation, endothelial cells and pericapillary cells activate and start producing proteases (collagenases and plasminogen activators) promoting the destruction of basal membrane, the detachment of these cells.

The interest of angiology is focused on therapeutic angiogenesis - a process aimed at managing impairments in insufficient tissue perfusion by stimulating the growth and arborization of blood vessels or endothelial function modulation. The formation and growth of new vessels in a postnatal period include the appearance of new capillaries and arterioles. Neoangiogenesis is the activation of endothelial cells, the synthesis of protease enzymes in them, degradation of intercellular matrix, proliferation and migration of endotheliocytes, and the formation of primary highly-permeable vascular structures followed by the stabilization and "growing-up" of primary vascular structures due to the attraction of pericapillary cells and smooth muscle cells resulting in organizing a threedimensional vascular network.

A key stimulus to angiogenesis in pathological conditions is hypoxia or ischemia, which induce the formation of many angiogenic factors and, primarily, the main angiogenesis regulator in both an embryonic and also postnatal period of body development: VEGF and its receptors. VEGF selectively stimulates the proliferation and migration of endothelial cells, their precursors and monocytes synthesizing the receptors to it. It enhances vascular permeability promoting plasma protein transudation to perivascular space, which should be prepared for migration of endothelial cells. VEGF causes the synthesis of endothelial NO-synthase and NO formation that contributes to vasodilation and stimulates the formation of proteases enzymes destroying the relations between endothelial cells and extracellular matrix that is necessary for cell trafficking. Prolonged local presence of VEGF is of importance during the stabilization and "growing-up" of a newly formed immature vascular network. Genetic constructions function in a target tissue from one to several weeks, and provide the longer presence of angiogenic factors.

A great number of neo-angiogenesis stimulators have been distinguished: VEGF, fibroblast growth factor (FGF), hepatocyte growth factor (HGF), angiogenin, angiopoietin. In addition, there have been found nonspecific vascular growth stimulators, such as insulinlike growth factor 1 (IGF-1), transforming growth factor, TNF- $\alpha$, nitric oxide, IL-8, matrix metalloproteinases. However, the extensive use of angiogenic factors, e.g., FGF, eventually can result in angiogenesis enhancement and active formation of vascularized atheromatous foci [142]. Induced proliferation of vascular endothelium, its translation in the intimal 
space with the formation of microvessels under angiogenesis stimulation is likely to be troublesome. The displacement of inflammation and angiogenesis center from the sub-intimal to para-adventitial space requires close attention of researchers.

VEGF is a significant and the most investigated factor. Fibroblast growth factor that can independently stimulate neo-angiogenesis has a synergistic effect with VEGF. VEGF is an angiogenic glycoprotein increasing vascular permeability. It is produced by different cell types [143], and endothelial cells have the receptors for the factor actively producing it under hypoxia or anoxia [144146]. Experimental and clinical works on therapeutic angiogenesis have used the modulation strategy of both endo-angiogenous growth factors (FGF-1, FGF-2, VEGF165) and their genes (VEGF165, VEGF121, VEGF189, FGF-5), and also the administration of recombinant exogenous agents. Their effect has been studied in patients with lower limb vascular ischemia, and on hind limb ischemic models in small and middlesized rodents, and acute and chronic myocardial ischemic models in dogs and mini pigs [147-151]. Scientific researches offer the challenges confirming or denying an actual mitogenic effect of VEGF on vascular endothelium [152]. Without dwelling on the results of these numerous studies in detail, it is necessary to mention the main thing: nearly all the cases, when growth factors or their genes were administered, were found to have stimulated the development of collaterals and new capillaries, which did not regress after discontinuation of growth factors administration; numerous introduction of the gene substituted numerous injections or infusions of recombinant growth factors. It is of importance that the administration of genes was accompanied by none or slight side effects, e.g., hypotension, which was observed when growth factors were administered. And, finally, the intramuscular administration of plasmid DNA without adenoviral vector managed to stimulate effectively angiogenesis and arteriogenesis in ischemic lower limbs.

The world laboratories engaged in gene therapeutic preparations are being currently at different stages. So, in China, there are two genetic therapeutic agents on the market - Gendicine and H101 designed to treat advanced cases of head and neck skin cancer. In Europe and USA, some genetic therapeutic pharmaceuticals are at the $3^{\text {rd }}$ phase of clinical trials. Collategene, a pharmaceutical engineered in Japan to treat the conditions associated with critical lower limb ischemia, is at the extended $3^{\text {rd }}$ phase of clinical trials in the United States, Europe, Japan, and other countries. Preliminary research protocols have been approved by FDA. FDA is known to have provided fast track designation program for Collategene. The program implies an accelerated prosecution for the preparations, which have demonstrated a high potential for solving the problem with unfulfilled medical needs in serious diseases.
In the early 2000s in Russia, there were carried out the first studies and pilot clinical trials of genetic therapeutic constructions designed on the basis of a gene encoding VEGF. In 2012 Neovasculgen, a new Russian pharmaceutical with VEGF165 gene, designed for managing chronic lower limb ischemia came to the market. Neovasculgen is an innovation and unique product in the world market. Its mode of action is based on a principle of a controlled therapeutic angiogenesis. Neovasculgen is a circular DNA molecule, which contains a region responsible for VEGF synthesis. Local multifocal administration of the agent into lower limb muscles provides controlled angiogenesis, stimulating growth and development of new vessels [153-157].

Protonated gel forms of hydrochloride and chitosan ascorbate, as well as chitosan sulfated form implanted in the perivascular fascial layer in rats result in significant local extraction of total lipid fractions, LDL and triglycerides from the femoral artery wall, by reducing their level, respectively, by $2.2,2.5$, and 1.9 times $[12,13]$. The implantation of liquid polymer forms demonstrates local recovery of the middle layer thickness by $29-38 \%$ reducing the relation of the media thickness to the vascular lumen diameter by $37-44 \%$. The effect was also observed in the overlying segment of a major vessel. Dislocation of sulfated chitosan form in the perivascular space within 20 days provides the decrease of a sub-intimal myocyte coefficient in the middle arterial segment by $27 \%$ enhancing a reconstruction effect in the upper vascular segment by $68 \%$. An implantation effect concerns the new formation of microvascular bed at the site of polymer resorption increasing the number of new vessels in rats by $22-49 \%$, in rabbits - by $56-66 \%$. The more profound effect of therapeutic angiogenesis is also clearly observed when chitosan constructions are implanted in animal intact tissues, on day 30 of a post-implantation period the increase being $85-96 \%$. The rearrangement of intimal and sub-intimal space of a major artery at early stages of atherogenic inflammation provides the local perfusion increase of limb soft tissues 20 days after implantation, by $68-86 \%$ on average. On day 30 of post-implantation period perfusion decreases, though being $34-36 \%$ higher compared to a control area $[12,13]$.

The mentioned findings of a local angiogenic effect of chitosan hydrogels are confirmed by fundamental researches, when using in experiment noncovalent and covalent copolymers containing chitosan and sulfated ingredient, heparin serving as an example. An angiogenic effect develops due to binding of proangiogenic growth factors by heparin fixed on copolymer [158-160]. However, the role of heparin is not obligatory. In fact, any biodegradable copolymers containing chitosan are able to bind and release angiogenic growth factors resulting, in their biodegradability, in the formation and growth of vascular tissue [161, 162]. When using chitosan biopolymers, VEGFs and those of the vessels proper, as well as multipotent cells being 
a part of a hydrogel, are safely protected by a chitosan polymer against temperature factors and the effect of hydrolyzing enzymes [126].

Thus, the diagnostics of separate markers in atherogenic inflammation analysis is confined by nature to form a strategy for controlling atherogenesis [38]. Current strategy in atherogenic inflammation study with a view to advanced technologies of making drug and medical products aimed at indirect and direct effective control of molecule-cell-tissue structures of vascular walls with early atheromatosis requires revealing fine reconstruction mechanisms. The analysis of molecular markers indicating atherogenic inflammation and considering anti-atherogenic direction of modern treatment technologies for chronic lower limb ischemia will enable to develop a control algorithm in the disease development and progression. Perivascular space should become one of the main application points for anti-atherogenic control mechanisms.

Study Funding. The study was supported by Russian Foundation for Basic Research, Krasnoyarsk Territory government, Krasnoyarsk Territory Foundation for Scientific and Applied Research Activity Support within the framework of a scientific project No.16-44-240506.

Conflicts of Interest. The authors have no conflicts of interest related to the present study.

\section{References}

1. European Stroke Organisation, Tendera M., Aboyans V., Bartelink M.L., Baumgartner I., Clément D., Collet J.P., Cremonesi A., De Carlo M., Erbel R., Fowkes F.G., Heras M., Kownator S., Minar E., Ostergren J., Poldermans D., Riambau V., Roffi M., Röther J., Sievert H., van Sambeek M., Zeller T.; ESC Committee for Practice Guidelines. ESC Guidelines on the diagnosis and treatment of peripheral artery diseases: document covering atherosclerotic disease of extracranial carotid and vertebral, mesenteric, renal, upper and lower extremity arteries: the Task Force on the Diagnosis and Treatment of Peripheral Artery Diseases of the European Society of Cardiology (ESC). Eur Heart J 2011; 32(22): 28512906, https://doi.org/10.1093/eurheartj/ehr211.

2. Olin J.W., Sealove B.A. Peripheral artery disease: current insight into the disease and its diagnosis and management. Mayo Clin Proc 2010; 85(7): 678-692, https:/l doi.org/10.4065/mcp.2010.0133.

3. Writing Committee to Develop Clinical Data Standards for Peripheral Atherosclerotic Vascular Disease, Creager M.A., Belkin M., Bluth E.I., Casey D.E. Jr., Chaturvedi S., Dake M.D., Fleg J.L., Hirsch A.T., Jaff M.R., Kern J.A., Malenka D.J., Martin E.T., Mohler E.R. 3rd, Murphy T., Olin J.W., Regensteiner J.G., Rosenwasser R.H., Sheehan P., Stewart K.J., Treat-Jacobson D., Upchurch G.R. Jr., White C.J., Ziffer J.A., Hendel R.C., Bozkurt B., Fonarow G.C., Jacobs J.P., Peterson P.N., Roger V.L., Smith E.E., Tcheng J.E., Wang T., Weintraub W.S. 2012 ACCF/AHA/ACR/SCAI/SIR/STS/SVM/ SVN/SVS key data elements and definitions for peripheral atherosclerotic vascular disease: a report of the American College of Cardiology Foundation/American Heart Association Task Force on Clinical Data Standards (Writing Committee to Develop Clinical Data Standards for Peripheral Atherosclerotic
Vascular Disease). Circulation 2012; 125(2): 395-467, https:// doi.org/10.1161/cir.0b013e31823299a1.

4. Fowkes F.G., Rudan D., Rudan I., Aboyans V., Denenberg J.O., McDermott M.M., Norman P.E., Sampson U.K., Williams L.J., Mensah G.A., Criqui M.H. Comparison of global estimates of prevalence and risk factors for peripheral artery disease in 2000 and 2010: a systematic review and analysis. Lancet 2013; 382(9901): 1329-1340, https://doi.org/10.1016/s0140-6736(13)61249-0.

5. Schanzer A., Conte M.S. Critical limb ischemia. Curr Treat Options Cardiovasc Med 2010; 12(3): 214-229, https:// doi.org/10.1007/s11936-010-0076-7.

6. Baumgartner I. Peripheral artery occlusive disease a major contributor to cardiovascular public health burden. Eur Heart J 2015; 36(15): 894-896, https://doi.org/10.1093/ eurheartj/ehu438.

7. Reinecke $H_{\text {., }}$ Unrath M., Freisinger E., Bunzemeier $H_{\text {., }}$ Meyborg M., Lüders F., Gebauer K., Roeder N., Berger K., Malyar N.M. Peripheral arterial disease and critical limb ischaemia: still poor outcomes and lack of guideline adherence. Eur Heart J 2015; 36(15): 932-938, https://doi.org/10.1093/ eurheartj/ehv006.

8. Nehler M.R., Duval S., Diao L., Annex B.H., Hiatt W.R., Rogers K., Zakharyan A., Hirsch A.T. Epidemiology of peripheral arterial disease and critical limb ischemia in an insured national population. J Vasc Surg 2014; 60(3): 686695.e2, https://doi.org/10.1016/j.jvs.2014.03.290.

9. Gulati A., Garcia L., Acharji S. Epidemiology of chronic critical limb ischemia. In: Critical limb ischemia. Springer International Publishing; 2016; p. 9-14, https://doi. org/10.1007/978-3-319-31991-9_2.

10. Karpov Yu.A., Sorokin E.V. Intensive medical treatment of patients with atherosclerosis. Kardiologiya 2005; 45(8): 4-7.

11. Bolshakov I.N., Dolgikh O.A., Kirichenko A.K., Kotikov A.R., Gorbunova V.O. Lipid spectrum and microcirculation when using biopolymers in an atherogenesis model. Fundamental'nye issledovaniya 2009; S7: 41-42.

12. Bolshakov I.N., Shestakova L.A., Kotikov A.R., Kaptyuk G.I. The experimental atherosclerotic inflammation of the main arteries in rabbits. Low traumatic technology of morphological reconstruction of the vascular wall at the early atherosclerotic stages. Fundamental'nye issledovaniya 2013; 8-2: 343-350.

13. Bolshakov I.N., Shestakova L.A., Kotikov A.R., Kaptyuk G.I. Experimental atherosclerosis in rats. Morphological reconstruction of the main artery wall with the polyssacharide biopolymers. Fundamental'nye issledovaniya 2013; 10-3: 557-563.

14. Alimohammadi M., Pichardo-Almarza C., Agu O., DíazZuccarini V. A multiscale modelling approach to understand atherosclerosis formation: a patient-specific case study in the aortic bifurcation. Proc Inst Mech Eng H 2017; 231(5): 378390, https://doi.org/10.1177/0954411917697356.

15. Steinman D.A. Image-based computational fluid dynamics: a new paradigm for monitoring hemodynamics and atherosclerosis. Curr Drug Targets Cardiovasc Haematol Disord 2004; 4(2): 183-197, https://doi. org/10.2174/1568006043336302.

16. Gimbrone M.A., García-Cardeña G. Vascular endothelium, hemodynamics, and the pathobiology of atherosclerosis. Cardiovasc Pathol 22(1): 9-15, https://doi. org/10.1016/j.carpath.2012.06.006.

17. Corti R., Fuster V. Imaging of atherosclerosis: magnetic 
resonance imaging. Eur Heart $J$ 2011; 32(14): 1709-1719, https://doi.org/10.1093/eurheartj/ehr068.

18. Tabas I., Williams K.J., Boren J. Subendothelial lipoprotein retention as the initiating process in atherosclerosis: update and therapeutic implications. Circulation 2007; 116(16): 1832-1844, https://doi.org/10.1161/circulationaha.106.676890.

19. Nielsen L.B., Gronholdt M.L.M., Schroeder T.V., Stender S., Nordestgaard B.G. In vivo transfer of lipoprotein(a) into human atherosclerotic carotid arterial intima. Arterioscler Thromb Vasc Biol 1997; 17(5): 905-911, https://doi. org/10.1161/01.atv.17.5.905.

20. Bartels E.D., Christoffersen C., Lindholm M.W., Nielsen L.B. Altered metabolism of LDL in the arterial wall precedes atherosclerosis regression novelty and significance. Circ Res 2015; 117(11): 933-942, https://doi.org/10.1161/ circresaha.115.307182.

21. Nordestgaard B.G., Tybjaerg-Hansen A., Lewis B. Influx in vivo of low density, intermediate density, and very low density lipoproteins into aortic intimas of genetically hyperlipidemic rabbits. Roles of plasma concentrations, extent of aortic lesion, and lipoprotein particle size as determinants. Arterioscler Thromb 1992; 12(1): 6-18, https://doi.org/10.1161/01. atv.12.1.6.

22. Donnelly L.H., Bree M.P., Hunter S.E., Keith J.C. Jr., Schaub R.G. Immunoreactive macrophage colony-stimulating factor is increased in atherosclerotic lesions of Watanabe heritable hyperlipidemic rabbits after recombinant human macrophage colony-stimulating factor therapy. Mol Reprod Dev 1997; 46(1): 92-95, https://doi.org/10.1002/(sici)10982795(199701)46:1<92::aid-mrd14>3.0.co;2-5.

23. Shi W., Wang X., Shih D.M., Laubach V.E., Navab M., Lusis A.J. Paradoxical reduction of fatty streak formation in mice lacking endothelial nitric oxide synthase. Circulation 2002; 105(17): 2078-2082, https://doi.org/10.1161/01. cir.0000015853.59427.32.

24. Poulsen C.B., Al-Mashhadi A.L., von Wachenfeldt K., Bentzon J.F., Nielsen L.B., Al-Mashhadi R.H., Thygesen J., Tolbod L., Larsen J.R., Frøkiær J., Tawakol A., Vucic E., Fredrickson J., Baruch A., Frendéus B., Robertson A.K., Moestrup S.K., Drouet L., Falk E. Treatment with a human recombinant monoclonal IgG antibody against oxidized LDL in atherosclerosis-prone pigs reduces cathepsin $S$ in coronary lesions. Inter J Cardiology 2016; 215: 506-515, https://doi. org/10.1016/j.jijcard.2016.03.222.

25. Salonen J.T., Ylä-Herttuala S., Yamamoto R., Butler S., Korpela H., Salonen R., Nyyssönen K., Palinski W., Witztum J.L. Autoantibody against oxidised LDL and progression of carotid atherosclerosis. Lancet 1992; 339(8798): 883-887, https://doi.org/10.1016/0140-6736(92)90926-t.

26. Bergmark C., Wu R., de Faire U., Lefvert A.K., Swedenborg J. Patients with early-onset peripheral vascular disease have increased levels of autoantibodies against oxidized LDL. Arterioscler Thromb Vasc Biol 1995; 15(4): 441445, https://doi.org/10.1161/01.atv.15.4.441.

27. Shogenova M.H., Zhetisheva R.A., Karpov A.M., Dotsenko Y.V., Masenko V.P., Naumov V.G. The role of oxidized low-density lipoproteins and antibodies against oxidized lowdensity lipoproteins in the immune and inflammatory process in atherosclerosis. Ateroskleroz i dislipidemii 2015; 2: 17-21.

28. Michelsen K.S., Arditi M. Toll-like receptor signaling and atherosclerosis. Curr Opin Hematol 2006; 13(3): 163-168, https://doi.org/10.1097/01.moh.0000219662.88409.7c.

29. Stoll G., Bendszus M. Inflammation and atherosclerosis: novel insights into plaque formation and destabilization. Stroke 2006; 37(7): 1923-1932, https://doi.org/10.1161/01. str.0000226901.34927.10.

30. Groyer É., Caligiuri G., Laschet-Khallou J., Nicoletti A. Immunological aspects of atherosclerosis. Presse Med 2006; 35(3Pt 2): 475-486, https://doi.org/10.1016/s07554982(06)74622-x.

31. Rajendran P., Rengarajan T., Thangavel J., Nishigaki Y., Sakthisekaran D., Sethi G., Nishigaki I. The vascular endothelium and human diseases. Int J Biol Sci 2013; 9(10): 1057-1069, https://doi.org/10.7150/ijbs.7502.

32. Kalinin R.E., Gryaznov S.V., Nikiforov A.A., Kamaev A.A., Shvalb A.P., Slepnev A.A. Nitric oxide synthase and endothelin-1 gene polymorphism in lower limb chronic venous insufficiency. I.P. Pavlov Russian Medical Biological Herald 2015; 23(4): 97, https://doi.org/10.17816/ pavlovj2015497-102.

33. Dow C.A., Templeton D.L., Lincenberg G.M., Greiner J.J., Stauffer B.L., DeSouza C.A. Elevations in C-reactive protein and endothelin-1 system activity in humans. Life Sci 2016; 159: 66-70, https://doi.org/10.1016/j. Ifs.2015.12.030.

34. Trinity J.D., Barrett-O'Keefe Z., Ives S.J., Morgan G., Rossman M.J., Donato A.J., Runnels S., Morgan D.E., Gmelch B.S., Bledsoe A.D., Richardson R.S., Wray D.W. Endogenous endothelin-1 and femoral artery shear rate: impact of age and implications for atherosclerosis. J Hypertens 2016; 34(2): 266-273, https://doi.org/10.1097/ hjh.0000000000000777.

35. Shelest B.A. Peripheral vessel wall changes in hypertensive patients with gout. Ter Arkh 2016; 88(5): 43-46, https://doi.org/10.17116/terarkh201688543-46.

36. Pavlides S., Gutierrez-Pajares J.L., Katiyar S., Jasmin J.F., Mercier I., Walters R., Pavlides C., Pestell R.G., Lisanti M.P., Frank P.G. Caveolin-1 regulates the antiatherogenic properties of macrophages. Cell Tissue Res 2014; 358(3): 821-831, https://doi.org/10.1007/s00441-0142008-4.

37. Zborovskaya I.B., Galetskiy S.A., Komel'kov A.V. Microdomain forming proteins in oncogenesis. Uspekhi molekulyarnoy onkologii 2016; 3(3): 16-29.

38. Engelberger R.P., Limacher A., Kucher N., Baumann F., Silbernagel G., Benghozi R., Do D.D., Willenberg T., Baumgartner I. Biological variation of established and novel biomarkers for atherosclerosis: results from a prospective, parallel-group cohort study. Clin Chim Acta 2015; 447: 16-22, https://doi.org/10.1016/j.cca.2015.05.003.

39. Rozenberg I., Sluka S.H., Mocharla P., Hallenberg A., Rotzius P., Borén J., Kränkel N., Landmesser U., Borsig L., Lüscher T.F., Eriksson E.E., Tanner F.C. Deletion of L-selectin increases atherosclerosis development in ApoE-l- mice. PLoS One 2011; 6(7): e21675, https://doi.org/10.1371/journal. pone.0021675.

40. Skopec I.S., Vezikova N.N., Marusenko I.M., Barysheva O.Y., Malafeev A.V., Malygin A.N. Correlation of inflammation biomarkers with the traditional risk factors in patients with acute coronary syndrome. Rational Pharmacotherapy in Cardiology 2016; 12(2): 166-170, https:// doi.org/10.20996/1819-6446-2016-12-2-166-170.

41. Galkina E., Ley K. Vascular adhesion molecules in atherosclerosis. Arterioscler Thromb Vasc Biol 2007; 27(11): 2292-2301, https://doi.org/10.1161/atvbaha.107.149179.

42. Kitagawa K., Matsumoto M., Sasaki T., Hashimoto H., 
Kuwabara K., Ohtsuki T., Hori M. Involvement of ICAM-1 in the progression of atherosclerosis in APOE-knockout mice. Atherosclerosis 2002; 160(2): 305-310, https://doi. org/10.1016/s0021-9150(01)00587-1.

43. Signorelli S.S., Anzaldi M., Libra M., Navolanic P.M., Malaponte G., Mangano K., Quattrocchi C., Di Marco R., Fiore V., Neri S. Plasma levels of inflammatory biomarkers in peripheral arterial disease: results of a cohort study. Angiology 2016; 67(9): 870-874, https://doi. org/10.1177/0003319716633339.

44. Belokopytova I.S., Moskaletz O.V., Paleev F.N., Zotova O.V. The diagnostic value of adhesive molecules sICAM-1 and sVCAM-1 in ischemic heart disease. Ateroskleroz i dislipidemii 2013; 4(12): 62-65.

45. Circulation research thematic synopsis: atherosclerosis. Circ Res 2013; 112(10): e118-e147, https://doi.org/10.1161/ circresaha.113.301487.

46. Al-Ghurabi M.E., Muhi A.A., Al-Mudhafar D.H. Vascular cell adhesion molecule-1 and endothelial leukocyte adhesion molecule- 1 as markers of atherosclerosis of NIDDM. American Journal of Life Sciences 2015; 3(1): 22-26, https://doi. org/10.11648/j.ajls.20150301.15.

47. Bala G., Blykers A., Xavier C., Descamps B., Broisat A., Ghezzi C., Fagret D., Van Camp G., Caveliers V., Vanhove C., Lahoutte T., Droogmans S., Cosyns B., Devoogdt N., Hernot S. Targeting of vascular cell adhesion molecule- 1 by $18 \mathrm{~F}$-labelled nanobodies for PET/CT imaging of inflamed atherosclerotic plaques. Eur Heart J Cardiovasc Imaging 2016; 17(9): 10011008, https://doi.org/10.1093/ehjci/jev346.

48. $\mathrm{Ni}$ W., Egashira K., Kitamoto S., Kataoka C., Koyanagi M., Inoue S., Imaizumi K., Akiyama C., Nishida K.I., Takeshita A. New anti-monocyte chemoattractant protein-1 gene therapy attenuates atherosclerosis in apolipoprotein E-knockout mice. Circulation 2001; 103(16): 2096-2101, https://doi.org/10.1161/01.cir.103.16.2096.

49. Tsai M.K., Hsieh C.C., Kuo H.F., Lee M.S., Huang M.Y., Kuo C.H., Hung C.H. Effect of prostaglandin 12 analogs on monocyte chemoattractant protein-1 in human monocyte and macrophage. Clin Exp Med 2015; 15(3): 245-253, https://doi. org/10.1007/s10238-014-0304-7.

50. Kim C.H., Mitchell J.B., Bursill C.A., Sowers A.L., Thetford A., Cook J.A., van Reyk D.M., Davies M.J. The nitroxide radical TEMPOL prevents obesity, hyperlipidaemia, elevation of inflammatory cytokines, and modulates atherosclerotic plaque composition in apoE-l- mice. Atherosclerosis 2015; 240(1): 234-241, https://doi. org/10.1016/j.atherosclerosis.2015.03.012.

51. Saitoh T., Kishida H., Tsukada Y., Fukuma Y., Sano J., Yasutake M., Fukuma N., Kusama Y., Hayakawa H. Clinical significance of increased plasma concentration of macrophage colony-stimulating factor in patients with angina pectoris. $\mathrm{J} \mathrm{Am}$ Coll Cardiol 2000; 35(3): 655-665, https://doi.org/10.1016/ s0735-1097(99)00583-5.

52. Nozadze D.N., Rvacheva A.V., Kaznacheeva E.I., Sergienko I.V. Monocytes in the development and destabilization of atherosclerotic plaques. Ateroskleroz $i$ dislipidemii 2012; 3: 25-36.

53. Cybulsky M.I., Cheong C., Robbins C.S. Macrophages and dendritic cells: partners in atherogenesis. Circ Res 2016; 118(4): 637-652, https://doi.org/10.1161/circresaha.115.306542.

54. Seshiah P.N., Kereiakes D.J., Vasudevan S.S., Lopes N., Su B.Y., Flavahan N.A., Goldschmidt-Clermont P.J. Activated monocytes induce smooth muscle cell death: role of macrophage colony-stimulating factor and cell contact. Circulation 2002; 105(2): 174-180, https://doi.org/10.1161/ hc0202.102248.

55. Lind L., Siegbahn A., Lindahl B., Stenemo M., Sundström J., Ärnlöv J. Discovery of new risk markers for ischemic stroke using a novel targeted proteomics chip. Stroke 2015; 46(12): 3340-3347, https://doi.org/10.1161/ strokeaha.115.010829.

56. Andrés V., Pello O.M., Silvestre-Roig C. Macrophage proliferation and apoptosis in atherosclerosis. Curr Opin Lipidol 2012; 23(5): 429-438, https://doi.org/10.1097/ mol.0b013e328357a379.

57. Kan X.H., Zhong X.Z., Zhang W.D., Shi C.Y. Increased circulating macrophage-colony stimulating factor and monocyte chemoattractant protein-1 are predictors of in-hospital events in Chinese patients with unstable angina pectoris. Int $J$ Clin Exp Pathol 2016; 9(2): 2021-2026.

58. Brånén L., Hovgaard L., Nitulescu M., Bengtsson E., Nilsson J., Jovinge S. Inhibition of tumor necrosis factor-alpha reduces atherosclerosis in apolipoprotein $\mathrm{E}$ knockout mice. Arterioscler Thromb Vasc Biol 2004; 24(11): 2137-2142, https://doi.org/10.1161/01.atv.0000143933.20616.1b.

59. Ohta H., Wada H., Niwa T., Kirii H., Iwamoto N., Fujii H., Saito K., Sekikawa K., Seishima M. Disruption of tumor necrosis factor-alpha gene diminishes the development of atherosclerosis in ApoE-deficient mice. Atherosclerosis 2005; 180(1): 11-17, https://doi.org/10.1016/j. atherosclerosis.2004.11.016.

60. Kober F., Canault M., Peiretti F., Mueller C., Kopp F., Alessi M.C., Cozzone P.J., Nalbone G., Bernard M. MRI followup of TNF-dependent differential progression of atherosclerotic wall-thickening in mouse aortic arch from early to advanced stages. Atherosclerosis 2007; 195(2): e93-e99, https://doi. org/10.1016/j.atherosclerosis.2007.06.015.

61. Chew M., Zhou J., Daugherty A., Eriksson T., Ellermann-Eriksen S., Hansen P.R., Falk E. Thalidomide inhibits early atherogenesis in apoE-deficient mice. APMIS Supp/ 2003; 109: 113-116.

62. Boesten L.S., Zadelaar A.S., van Nieuwkoop A., Gijbels M.J., de Winther M.P., Havekes L.M., van Vlijmen B.J. Tumor necrosis factor-alpha promotes atherosclerotic lesion progression in $\mathrm{APOE}^{\star} 3$-Leiden transgenic mice. Cardiovasc Res 2005; 66(1): 179-185, https://doi.org/10.1016/j. cardiores.2005.01.001.

63. Canault M., Peiretti F., Mueller C., Kopp F., Morange P., Rihs S., Portugal H., Juhan-Vague I., Nalbone G. Exclusive expression of transmembrane TNF-alpha in mice reduces the inflammatory response in early lipid lesions of aortic sinus. Atherosclerosis 2004; 172(2): 211-218, https://doi. org/10.1016/j.atherosclerosis.2003.10.004.

64. Prasad S., Tyagi A.K., Aggarwal B.B. Detection of inflammatory biomarkers in saliva and urine: potential in diagnosis, prevention, and treatment for chronic diseases. Exp Biol Med 2016; 241(8): 783-799, https://doi. org/10.1177/1535370216638770.

65. Weintraub W.S., Harrison D.G. C-reactive protein, inflammation and atherosclerosis: do we really understand it yet? Eur Heart J 2000; 21(12): 958-960, https://doi. org/10.1053/euhj.2000.2109.

66. Libby P., Ridker P.M. Inflammation and atherosclerosis: role of C-reactive protein in risk assessment. $\mathrm{Am} \mathrm{J}$ Med 2004; 116(Suppl 6A): 9S-16S, https://doi.org/10.1016/j. amjmed.2004.02.006. 
67. Ikonomidis I., Lekakis J., Revela I., Andreotti F., Nihoyannopoulos P. Increased circulating C-reactive protein and macrophage-colony stimulating factor are complementary predictors of long-term outcome in patients with chronic coronary artery disease. Eur Heart J 2005; 26(16): 1618-1624, https://doi.org/10.1093/eurheartj/ehi192.

68. Koenig W. High-sensitivity C-reactive protein and atherosclerotic disease: from improved risk prediction to riskguided therapy. Int J Cardiol 2013; 168(6): 5126-5134, https:// doi.org/10.1016/j.ijcard.2013.07.113.

69. Yu Q., Liu Z., Waqar A.B., Ning B., Yang X., Shiomi M., Graham M.J., Crooke R.M., Liu E., Dong S., Fan J. Effects of antisense oligonucleotides against C-reactive protein on the development of atherosclerosis in WHHL rabbits. Mediators Inflamm 2014; 2014: 979132, https://doi. org/10.1155/2014/979132.

70. Cossette É., Cloutier I., Tardif K., DonPierre G., Tanguay J.F. Estradiol inhibits vascular endothelial cells proinflammatory activation induced by C-reactive protein. Mol Cell Biochem 2013; 373(1-2): 137-147, https://doi.org/10.1007/ s11010-012-1482-9.

71. Wang Q., Huo L., He J., Ding W., Su H., Tian D., Welch C., Hammock B.D., Ai D., Zhu Y. Soluble epoxide hydrolase is involved in the development of atherosclerosis and arterial neointima formation by regulating smooth muscle cell migration. Am J Physiol Heart Circ Physiol 2015; 309(11): H1894-H1903, https://doi.org/10.1152/ajpheart.00289.2015.

72. Wu M.D., Atkinson T.M., Lindner J.R. Platelets and von Willebrand factor in atherogenesis. Blood 2017; 129(11): 1415-1419, https://doi.org/10.1182/blood-2016-07-692673.

73. Ricci C., Ferri N. Naturally occurring PDGF receptor inhibitors with potential anti-atherosclerotic properties. Vascul Pharmacol 2015; 70: 1-7, https://doi.org/10.1016/j. vph.2015.02.002.

74. Lee M.H., Kwon B.-J., Koo M.-A., You K.E., Park J.-C. Mitogenesis of vascular smooth muscle cell stimulated by platelet-derived growth factor-bb is inhibited by blocking of intracellular signaling by epigallocatechin-3-O-gallate. Oxid Med Cell Longev 2013; 2013: 827905, https://doi. org/10.1155/2013/827905.

75. Sihvola R. Platelet-derived growth factor and proinflammatory cytokines in cardiac allograft arteriosclerosis. Academic Dissertation. Helsinki; 2003.

76. Heldin C.H., Westermark B. Mechanism of action and in vivo role of platelet-derived growth factor. Physiol Rev 1999; 79(4): 1283-1316.

77. Pope C.A., Bhatnagar A., McCracken J.P., Abplanalp W., Conklin D.J., O'Toole T. Exposure to fine particulate air pollution is associated with endothelial injury and systemic inflammation novelty and significance. Circ Res 2016; 119(11): 1204-1214, https://doi.org/10.1161/circresaha.116.309279.

78. Chi H., Messas E., Levine R.A., Graves D.T., Amar S. Interleukin-1 receptor signaling mediates atherosclerosis associated with bacterial exposure and/ or a high-fat diet in a murine apolipoprotein e heterozygote model: pharmacotherapeutic implications. Circulation 2004; 110(12): 1678-1685, https://doi.org/10.1161/01. cir.0000142085.39015.31.

79. von der Thüsen J.H., Kuiper J., van Berkel T.J., Biessen E.A. Interleukins in atherosclerosis: molecular pathways and therapeutic potential. Pharmacol Rev 2003; 55(1): 133-166, https://doi.org/10.1124/pr.55.1.5.

80. Vicenová B., Vopálenský V., Burýsek L., Pospísek M.
Emerging role of interleukin-1 in cardiovascular diseases. Physiol Res 2009; 58(4): 481-498, https://doi.org/10.1161/ circresaha.115.304437.

81. Folco E.J., Sukhova G.K., Quillard T., Libby P. Moderate hypoxia potentiates interleukin-1 $\beta$ production in activated human macrophages. Circ Res 2014; 115(10): 875-883, https://doi.org/10.1161/circresaha.115.304437.

82. Pagano P.J., Gutterman D.D. The adventitia: the outs and ins of vascular disease. Cardiovasc Res 2007; 75(4): 636639, https://doi.org/10.1016/j.cardiores.2007.07.006.

83. Edsfeldt A., Grufman H., Asciutto G., Nitulescu M., Persson A., Nilsson M., Nilsson J., Gonçalves I. Circulating cytokines reflect the expression of pro-inflammatory cytokines in atherosclerotic plaques. Atherosclerosis 2015; 241(2): 443449, https://doi.org/10.1016/j.atherosclerosis.2015.05.019.

84. Young J.L., Libby P., Schönbeck U. Cytokines in the pathogenesis of atherosclerosis. Thromb Haemost 2002; 88(4): 554-567.

85. Nakai Y., Iwabuchi K., Fujii S., Ishimori N., Dashtsoodol N., Watano K., Mishima T., Iwabuchi C., Tanaka S., Bezbradica J.S., Nakayama T., Taniguchi M., Miyake S., Yamamura T., Kitabatake A., Joyce S., Van Kaer L., Onoé K. Natural killer T cells accelerate atherogenesis in mice. Blood 2004; 104(7): 2051-2059, https://doi.org/10.1182/ blood-2003-10-3485.

86. Aslanian A.M., Chapman H.A., Charo I.F. Transient role for CD1d-restricted natural killer $T$ cells in the formation of atherosclerotic lesions. Arterioscler Thromb Vasc Biol 2005; 25(3): 628-632, https://doi.org/10.1161/01. atv.0000153046.59370.13.

87. Voloshyna I., Littlefield M.J., Reiss A.B. Atherosclerosis and interferon-ү: new insights and therapeutic targets. Trends Cardiovasc Med 2014; 24(1): 45-51, https://doi.org/10.1016/j. tcm.2013.06.003.

88. Harvey E., Ramji D. Interferon-y and atherosclerosis: pro- or anti-atherogenic? Cardiovasc Res 2005; 67(1): 11-20, https://doi.org/10.1016/j.cardiores.2005.04.019.

89. Tavakoli N.N., Harris A.K., Sullivan D.R., Hambly B.D., Bao S. Interferon-y deficiency reduces neointimal formation in a model of endoluminal endothelial injury combined with atherogenic diet. Int J Mol Med 2012; 30(3): 545-552, https:// doi.org/10.3892/ijmm.2012.1034.

90. Kunjathoor V.V., Febbraio M., Podrez E.A., Moore K.J., Andersson L., Koehn S., Rhee J.S., Silverstein R., Hoff H.F., Freeman M.W. Scavenger receptors class A-I/II and CD36 are the principal receptors responsible for the uptake of modified low density lipoprotein leading to lipid loading in macrophages. J Biol Chem 2002; 277(51): 49982-49988, https://doi. org/10.1074/jbc.m209649200.

91. Febbraio M., Podrez E.A., Smith J.D., Hajjar D.P., Hazen S.L., Hoff H.F., Sharma K., Silverstein R.L. Targeted disruption of the class B scavenger receptor CD36 protects against atherosclerotic lesion development in mice. $J$ Clin Invest 2000; 105(8): 1049-1056, https://doi.org/10.1172/jci9259.

92. Rigotti A. Scavenger receptors and atherosclerosis. Biol Res 2000; 33(2): 97-103, https://doi.org/10.4067/s071697602000000200009.

93. Mrochek A.G., Stel'mashok V.I., Adzerikho I.E., Savchuk A.I., Avdey P.P. A case of a successful restoration of limb blood supply by percutaneous ultrasound angioplasty in a patient with obliterating atherosclerosis of the left superficial femoral artery. Angiologiya i sosudistaya khirurgiya 2002; 8(1): 100-104. 
94. Alekyan B.G., Dubrovskiy V.A., Stepanov A.D., Filatov E.N., Khazov I.A. Sredstvo dlya podderzhaniya prosveta sosuda ili pologo organa [An agent to maintain a lumen of a vessel or a hollow organ]. Patent RU 2169544. 2001

95. Karpov D.A., Kochanov I.N., Kislov I.F., Mazaev S.N., Samko A.N., Sukhov V.K. Vnutrisosudistyy protez dlya vosstanovleniya i/ili sokhraneniya prosveta krovenosnogo sosuda (varianty) [Intravascular prosthesis for blood vessel recanalization and/or maintenance (variants)]. Patent RU 2253410. 2005.

96. Tu J.V., Wang H., Bowyer B., Green L., Fang J., Kucey D.; Participants in the Ontario Carotid Endarterectomy Registry. Risk factors for death or stroke after carotid endarterectomy: observations from the Ontario Carotid Endarterectomy Registry. Stroke 2003; 34(11): 2568-1573, https://doi.org/10.1161/01.str.0000092491.45227.0f.

97. L'Heureux N., Dusserre N., Konig G., Victor B., Keire P., Wight T.N., Chronos N.A., Kyles A.E., Gregory C.R., Hoyt G., Robbins R.C., McAllister T.N. Human tissue-engineered blood vessels for adult arterial revascularization. Nat Med 2006; 12(3): 361-365, https://doi.org/10.1038/nm1364.

98. Spiridonov A.A., Morozov K.M., Fedorovich A.A. Sposob khirurgicheskogo lecheniya khronicheskoy kriticheskoy ishemii nizhnikh konechnostey [A surgical modality of chronic critical lower limb ischemia]. Patent RU 2206274. 2003.

99. Troitsky A.V., Lysenko Ye.R., Khabazov R.I., Orekhov P.Yu., Parshin P.Yu., Korolev V.I., Ustyantseva N.V., Malyutina Ye.D., Nishchenko A.V. Results of primary reconstructions in patients with lesion of the tibial arteries. Angiologiya i sosudistaya khirurgiya 2003; 9(1): 102-108.

100. Mumladze R.B., Nartov A.P. Sposob lecheniya bol'nykh s khronicheskoy arterial'noy nedostatochnost'yu nizhnikh konechnostey [A treatment modality for patients with chronic arterial insufficiency of lower limbs]. Patent RU 2162356. 2001.

101. Suchkova Zh.V., Byalovskiy Yu.Yu., Morozov V.N., Khadartsev A.A. Sposob lecheniya ateroskleroticheskikh porazheniy sosudov nizhnikh konechnostey [A treatment modality of arterial sclerotic disease of lower limb vessels]. Patent RF 2261734. 2005.

102. Natsional'nye rekomendatsii po vedeniyu patsientov $s$ zabolevaniyami arteriy nizhnikh konechnostey. Rossiyskiy soglasitel'nyy document [National guidelines on managing patients with lower limb arterial diseases. Russian conciliation document]. Moscow; 2013.

103. Bolshakov I.N., Dolgikh O.A., Kirichenko A.K., Kotikov A.R., Gorbunova V.O. Wall vessel reconstruction in atherogenesis using chitosan biopolymers. Fundamental'nye issledovaniya 2009; S7: 42-43.

104. Dolgih O.A., Gorbunova V.O. Experimental justification of natural biopolymers reconstruction of magistral arteries in low extremities in case of modeled atherogenesis. Sibirskoe meditsinskoe obozrenie 2009; 3(57): 88-90.

105. Kotikov A.R., Dolgikh O.A., Gorbunova V.O., Bolshakov I.N., Zykova L.D. Morfometriya sosudov nizhnikh konechnostey posle maloinvazivnoy rekonstruktsii sul'fatirovannym proizvodnym khitozana pri eksperimental'nom aterogeneze. $\mathrm{V}$ kn.: Materialy $X$ Mezhdunarodnoy konferentsii "Sovremennye perspektivy $v$ issledovanii khitina $i$ khitozana" [Lower limb vessel morphometry after minimally invasive reconstruction by sulphated chitosan derivative in experimental atherogenesis. In: Proceedings of $X$ International conference
"Modern prospects in chitin and chitosan studies"]. Nizhny Novgorod; 2010; p. 204-207.

106. Bolshakov I.N., Shestakova L.A., Kirichenko A.K., Ali-Riza A.E., Kotikov A.R., Dolgikh O.A., Gorbunova V.O. Maloinvazivnaya tekhnologiya angiogeneza pri rekonstruktsii stenki magistral'nykh sosudov nizhnikh konechnostey $v$ eksperimente. V kn.: Tezisy dokladov III Mezhdunarodnoy konferentsii "Sovremennye tekhnologii $i$ vozmozhnosti rekonstruktivno-vosstanovitel'noy i esteticheskoy khirurgii' [A minimally invasive angiogenesis technology in lower limb great vessel wall reconstruction in experiment. In: Abstracts of III International conference "Modern technologies and capabilities of reconstructive and esthetic surgery"]. Moscow; 2012; p. 59-61.

107. Bolshakov I.N., Shestakova L.A., Kotikov A.R. Maloinvazivnaya tekhnologiya angiogeneza pri rekonstruktsii stenki magistral'nykh sosudov nizhnikh konechnostey $\mathrm{v}$ eksperimente. V kn.: Materialy regional'noy nauchnoprakticheskoy konferentsii "Aktual'nye voprosy abdominal'noy $i$ sosudistoy khirurgii" [A minimally invasive angiogenesis technology in lower limb great vessel wall reconstruction in experiment. In: Proceedings of regional research and practice conference "Urgent issues of abdominal and vascular surgery"]. Barnaul; 2012; p. 96-97.

108. Polignano R., Baggiore C., Falciani F., Restelli U., Troisi N., Michelagnoli S., Panigada G., Tatini S., Farina A., Landini G. Efficacy, safety and feasibility of intravenous iloprost in the domiciliary treatment of patients with ischemic disease of the lower limbs. Eur Rev Med Pharmacol Sci 2016; 20(17): 3720-3726.

109. Norgren L., Hiatt W.R., Dormandy J.A., Nehler M.R., Harris K.A., Fowkes F.G.R. Inter-society consensus for the management of peripheral arterial disease (TASC II). Eur $J$ Vasc Endovasc Surg 2007; 33(1): S1-S75, https://doi. org/10.1016/j.ejvs.2006.09.024.

110. Meini S., De Franco V., Auteri A., Setacci C., Di Renzo M., Pieragalli D. Short-term and long-term effects of one-week treatment with intravenous iloprost in critical limb ischemia patients (Leriche-Fontaine stage III and IV). Int Angiol 2005; 24(1): 64-69.

111. Gavrilenko A.V., Kotov A.E., Loikov D.A. Surgical treatment of critical lower limb ischemia in diabetic patients. Annaly khirurgii 2012; (2): 10-15.

112. Pels K., Deiner C., Coupland S.E., Noutsias M., Sutter A.P., Schultheiss H.P., Yla-Herttuala S., Schwimmbeck P.L. Effect of adventitial VEGF(165) gene transfer on vascular thickening after coronary artery balloon injury. Cardiovasc Res 2003; 60(3): 664-672, https://doi. org/10.1016/j.cardiores.2003.09.003.

113. Skóra J., Barć P., Dawiskiba T., Baczyńska D., Mastalerz-Migas A. Angiogenesis after plasmid VEGF165 gene transfer in an animal model. Cent Eur J Immunol 2013; 3: 305309, https://doi.org/10.5114/ceji.2013.37751.

114. Deev R.V., Kalinin R.E., Chervyakov Y.V., Gryaznov S.G., Mzhavanadze N.D., Kiselev S.L., Isaev A.A., Schwalb P.G., Staroverov I.N., Nersessian E.G. Results of gentherapeutic drug "Neovasculgen" in patients with chronic lower limb ischemia: 1 year of observation. Vestnik Natsional'nogo mediko-khirurgicheskogo Tsentra im. N.I. Pirogova 2011; 6(4): $20-25$.

115. Chervyakov Yu.V., Staroverov I.N., Vlasenko O.N., Nersesyan E.G., Isaev A.A., Deev R.V. Remote results of treatment of patients with chronic lower-limb ischaemia 
by means of indirect revascularization and gene therapy. Angiologiya i sosudistaya khirurgiya 2016; 22(1): 29-37.

116. Deev R.V., Grigoryan A.S., Potapov I.V., Kiselev S.L., Isaev A.A. Worldwide experience and recent trends in gene therapy of ischaemic diseases. Angiologiya $i$ sosudistaya khirurgiya 2011; 17(2): 145-154.

117. Shval'b P.G., Gavrilenko A.V., Kalinin R.E., Chervyakov Yu.V., Voronov D.A., Staroverov I.N., Gryaznov S.V., Mzhavanadze N.D., Nersesyan E.G., Kiselev S.L., Isaev A.A., Deev R.V. Efficacy and safety of application "Neovasculgen" in the complex treatment patients with chronic lower limb ischemia (Ilb-III phase of clinical trials). Kletochnaya transplantologiya $i$ tkanevaya inzheneriya 2011; 6(3): 76-83.

118. Kalinin R.E., Suchkov I.A., Pshennikov A.S., Mzhavanadze N.D., Krylov A.A., Plaksa I.L., Deev R.V. Efficacy of medication for therapeutic angiogenesis in combined treatment of patients with diabetes mellitus and critical limb ischemia. Kazanskiy meditsinskiy zhurnal 2016; 97(5): 674680. https://doi.org/10.17750/kmj2016-674.

119. Kalinin R.E., Suchkov I.A., Mzhavanadze N.D., Krylov A.A., Plaksa I.L., Deev R.V. Experience of using gene therapy technologies in the management of patients with advanced peripheral atherosclerosis and severe diabetes mellitus. Angiologiya i sosudistaya khirurgiya 2016; 22(S2): 140-141.

120. Deev R.V., Plaksa I.L., Bozo I.Y., Isaev A.A. Longterm 5 years follow-up gene therapy for peripheral arterial disease. Human Gene Therapy 2016; 27(5): A101-A102.

121. Yudin M.A., Plaksa I.L., Mzhavanadze N.D., Krakovskii M.A., Bykov V.N., Mavlikeev M.O., Isaev A.A., Kalinin R.E., Deev R.V. Estimation of systemic distribution and angiogenic effect of pl-VEGF165 in the model of limb ischemia. Patologiya krovoobrashcheniya i kardiokhirurgiya 2015; 19(S4-2): 33-42.

122. Belousov E.Yu., Soroka V.V., Nochrin S.P., Ryazanov A.N. Experience of aniogenic therapy in the treatment of patients with chronic lower limb ischemia. Trudnyy patsient 2014; 12(10): 40-43.

123. Kleemann R., Zadelaar S., Kooistra T. Cytokines and atherosclerosis: a comprehensive review of studies in mice. Cardiovasc Res 2008; 79(3): 360-376, https://doi.org/10.1093/ cvr/cvn120.

124. Poredos P., Jezovnik M.K. The role of inflammatory biomarkers in the detection and therapy of atherosclerotic disease. Curr Vasc Pharmacol 2016; 14(6): 534-546, https:// doi.org/10.2174/1570161114666160625080104.

125. Kim S., Kawai T., Wang D., Yang Y. Engineering a dual-layer chitosan-lactide hydrogel to create endothelial cell aggregate-induced microvascular networks in vitro and increase blood perfusion in vivo. ACS Appl Mater Interfaces 2016; 8(30): 19245-19255, https://doi.org/10.1021/acsami.6b04431.

126. Lee S., Valmikinathan C.M., Byun J., Kim S., Lee G., Mokarram N., Pai S.B., Um E., Bellamkonda R.V., Yoon Y.S. Enhanced therapeutic neovascularization by CD31-expressing cells and embryonic stem cell-derived endothelial cells engineered with chitosan hydrogel containing VEGF-releasing microtubes. Biomaterials 2015; 63: 158-167, https://doi. org/10.1016/j.biomaterials.2015.06.009

127. Auger F.A., D'Orléans-Juste P., Germain L. Adventitia contribution to vascular contraction: hints provided by tissueengineered substitutes. Cardiovasc Res 2007; 75(4): 669-678, https://doi.org/10.1016/j.cardiores.2007.06.001.

128. Laflamme K., Roberge C.J., Grenier G.,
Rémy-Zolghadri M., Pouliot S., Baker K., Labbé R., D’OrléansJuste P., Auger F.A., Germain L. Adventitia contribution in vascular tone: insights from adventitia-derived cells in a tissueengineered human blood vessel. FASEB J 2006; 20(8): 12451247, https://doi.org/10.1096/fj.05-4702fje.

129. Herrmann J., Lerman L.O., Rodriguez-Porcel M., Holmes D.R. Jr., Richardson D.M., Ritman E.L., Lerman A. Coronary vasa vasorum neovascularization precedes epicardial endothelial dysfunction in experimental hypercholesterolemia. Cardiovasc Res 2001; 51(4): 762-766, https://doi.org/10.1016/s0008-6363(01)00347-9.

130. Han Y., Runge M.S., Brasier A.R. Angiotensin II induces interleukin-6 transcription in vascular smooth muscle cells through pleiotropic activation of nuclear factor-kappa B transcription factors. Circ Res 1999; 84(6): 695-703, https:// doi.org/10.1161/01.res.84.6.695.

131. Ni W., Kitamoto S., Ishibashi M., Usui M., Inoue S., Hiasa K., Zhao Q., Nishida K., Takeshita A., Egashira K. Monocyte chemoattractant protein-1 is an essential inflammatory mediator in angiotensin II-induced progression of established atherosclerosis in hypercholesterolemic mice. Arterioscler Thromb Vasc Biol 2004; 24(3): 534-539, https:// doi.org/10.1161/01.atv.0000118275.60121.2b.

132. Chan E.C., Datla S.R., Dilley R., Hickey H., Drummond G.R., Dusting G.J. Adventitial application of the NADPH oxidase inhibitor apocynin in vivo reduces neointima formation and endothelial dysfunction in rabbits. Cardiovasc Res 2007; 75(4): 710-718, https://doi.org/10.1016/j. cardiores.2007.06.005.

133. Potter C.M., Lao K.H., Zeng L., Xu Q. Role of biomechanical forces in stem cell vascular lineage differentiation. Arterioscler Thromb Vasc Biol 2014; 34(10): 2184-2190, https://doi.org/10.1161/atvbaha.114.303423.

134. Rey F.E., Pagano P.J. The reactive adventitia: fibroblast oxidase in vascular function. Arterioscler Thromb Vasc Biol 2002; 22(12): 1962-1971, https://doi.org/10.1161/01. atv.0000043452.30772.18.

135. Soto-Gutierrez A., Yagi H., Uygun B.E., NavarroAlvarez N., Uygun K., Kobayashi N., Yang Y.G., Yarmush M.L. Cell delivery: from cell transplantation to organ engineering. Cell Transplant 2010; 19(6): 655-665, https://doi. org/10.3727/096368910x508753.

136. Nugent H.M., Rogers C., Edelman E.R. Endothelial implants inhibit intimal hyperplasia after porcine angioplasty. Circ Res 1999; 84(4): 384-391, https://doi.org/10.1161/01. res.84.4.384.

137. Nugent H.M., Groothuis A., Seifert P., Guerraro J.L., Nedelman M., Mohanakumar T., Edelman E.R. Perivascular endothelial implants inhibit intimal hyperplasia in a model of arteriovenous fistulae: a safety and efficacy study in the pig. J Vasc Res 2002; 39(6): 524-533, https://doi. org/10.1159/000067207

138. Nugent H.M., Sjin R.T., White D., Milton L.G., Manson R.J., Lawson J.H., Edelman E.R. Adventitial endothelial implants reduce matrix metalloproteinase-2 expression and increase luminal diameter in porcine arteriovenous grafts. J Vasc Surg 2007; 46(3): 548-556, https://doi.org/10.1016/j.jvs.2007.04.074.

139. van der Valk F.M., Kuijk C., Verweij S.L., Stiekema L.C.A., Kaiser Y., Zeerleder S., Nahrendorf M., Voermans C., Stroes E.S.G. Increased haematopoietic activity in patients with atherosclerosis. Eur Heart J 2017; 38(6): 425432, https://doi.org/10.1093/eurheartj/ehw246. 
140. Van der Veken B., De Meyer G.R., Martinet W. Intraplaque neovascularization as a novel therapeutic target in advanced atherosclerosis. Expert Opin Ther Targets 2016; 20(10): 1247-1257, https://doi.org/10.1080/14728222.2016.11 86650

141. Suzuki J., Shimamura M., Suda H., Wakayama K., Kumagai H., Ikeda Y., Akazawa H., Isobe M., Komuro I., Morishita R. Current therapies and investigational drugs for peripheral arterial disease. Hypertens Res 2016; 39(4): 183191, https://doi.org/10.1038/hr.2015.134.

142. Liu M.H., Tang Z.H., Li G.H., Qu S.L., Zhang Y., Ren Z., Liu L.S., Jiang Z.S. Janus-like role of fibroblast growth factor 2 in arteriosclerotic coronary artery disease: atherogenesis and angiogenesis. Atherosclerosis 2013; 229(1): 10-17, https://doi.org/10.1016/j.atherosclerosis.2013.03.013.

143. Braghirolli D.I., Helfer V.E., Chagastelles P.C., Dalberto T.P., Gamba D., Pranke P. Electrospun scaffolds functionalized with heparin and vascular endothelial growth factor increase the proliferation of endothelial progenitor cells. Biomed Mater 2017; 12(2): 025003, https://doi. org/10.1088/1748-605x/aa5bbc.

144. Kaplanskaya I.B., Glasko E.N., Frank G.A. Angiogenesis, intercellular contacts and stromalparenchimatous relationships in health and disease. Rossiyskiy onkologicheskiy zhurnal 2005; 4: 53-57.

145. Gavrilenko T.I., Ryzhkova N.A., Parkhomenko A.N. Vascular endothelial growth factor in the clinic of internal diseases and its pathogenetic value. Ukrai'ns'kyj kardiologichnyj zhurnal 2011; 4: 87-95.

146. Hoeben A., Landuyt B., Highley M.S., Wildiers H., Van Oosterom A.T., De Bruijn E.A. Vascular endothelial growth factor and angiogenesis. Pharmacol Rev 2004; 56(4): 549 580, https://doi.org/10.1124/pr.56.4.3.

147. Barc P., Plonek T., Baczynska D., Radwanska A., Witkiewicz W., Halon A., Kupczynska-Markiewicz D., Strozecki L., Korta K., Skora J. A combination of VEGF165/ HGF genes is more effective in blood vessels formation than ANGPT1/VEGF165 genes in an in vivo rat model. Int $J$ Clin Exp Med 2016; 9(7): 12737-12744.

148. Makarevich P.I., Boldyreva M.A., Gluhanyuk E.V., Efimenko A.Y., Dergilev K.V., Shevchenko E.K., Sharonov G.V., Gallinger J.O., Rodina P.A., Sarkisyan S.S., Hu Y.C., Parfyonova Y.V. Enhanced angiogenesis in ischemic skeletal muscle after transplantation of cell sheets from baculovirustransduced adipose-derived stromal cells expressing VEGF165. Stem Cell Res Ther 2015; 6: 204, https://doi. org/10.1186/s13287-015-0199-6.

149. Vemulapalli S., Patel M.R., Jones W.S. Limb ischemia: cardiovascular diagnosis and management from head to toe. Curr Cardiol Rep 2015; 17(7): 611, https://doi. org/10.1007/s11886-015-0611-y.

150. Cooke J.P., Losordo D.W. Modulating the vascular response to limb ischemia: angiogenic and cell therapies. Circ Res 2015; 116(9): 1561-1578, https://doi.org/10.1161/ circresaha.115.303565.

151. Lederman R.J., Mendelsohn F.O., Anderson R.D., Saucedo J.F., Tenaglia A.N., Hermiller J.B., Hillegass W.B., Rocha-Singh K., Moon T.E., Whitehouse M.J., Annex B.H.; TRAFFIC Investigators. Therapeutic angiogenesis with recombinant fibroblast growth factor-2 for intermittent claudication (the TRAFFIC study): a randomised trial. Lancet 2002; 359(9392): 2053-2058, https://doi.org/10.1016/s01406736(02)08937-7.

152. Jazwa A., Florczyk U., Grochot-Przeczek A., Krist B., Loboda A., Jozkowicz A., Dulak J. Limb ischemia and vessel regeneration: is there a role for VEGF? Vascul Pharmacol 2016; 86: 18-30, https://doi.org/10.1016/j.vph.2016.09.003.

153. Bokeriya L.A., Eremeeva M.V., Kiselev S.L., Arakelyan V.S., Demidova O.A., Makarenko V.N. Creation and experience of using a VEGF-based agent in the treatment of chronic lower limb ischemia. Kletochnaya transplantologiya tkanevaya inzheneriya 2011; 6(1): 105.

154. Gavrilenko A.V., Voronov D.A., Bochkov N.P. Angiogenesis stimulation in an integrated therapy of patients with chronic lower limb ischemia (combination of reconstructive surgeries and genetically engineering technologies). Kletochnaya transplantologiya $i$ tkanevaya inzheneriya 2011; 6(1): 105-106.

155. Deev R.V., Kiselev S.L., Isaev A.A., Prikhod'ko A.V., Potapov I.V. Global experience of gene therapy of chronic lower limb ischemia CHD. Kletochnaya transplantologiya $i$ tkanevaya inzheneriya 2011; 6(1): 106.

156. Staroverov I.N., Chervyakov Yu.V., Kuz'min R.N., Nersesyan E.G., Deev R.V. The treatment results of patients with chronic obliterating diseases of lower limb arteries by an agent based on a gene encoding vascular endothelial growth factor (VEGF). Kletochnaya transplantologiya $i$ tkanevaya inzheneriya 2011; 6(1): 106-107.

157. Shval'b P.G., Kalinin R.E., Gryaznov S.V. The experience of using an agent based on VEGF gene in patients with chronic obliterating lower limb diseases. Kletochnaya transplantologiya i tkanevaya inzheneriya 2011; 6(1): 107.

158. Ding X., Gao J., Wang Z., Awada H., Wang Y. A shear-thinning hydrogel that extends in vivo bioactivity of FGF2. Biomaterials 2016; 111: 80-89, https://doi. org/10.1016/j.biomaterials.2016.09.026.

159. Shahzadi L., Yar M., Jamal A., Siddiqi S.A., Chaudhry A.A., Zahid S., Tariq M., Rehman I.U., MacNeil S. Triethyl orthoformate covalently cross-linked chitosan(poly vinyl) alcohol based biodegradable scaffolds with heparin-binding ability for promoting neovascularisation. $J$ Biomater Appl 2016; 31(4): 582-593, https://doi. org/10.1177/0885328216650125.

160. Yar M., Gigliobianco G., Shahzadi L., Dew L., Siddiqi S.A., Khan A.F., Chaudhry A.A., ur Rehman 1., MacNeil S. Production of chitosan PVA PCL hydrogels to bind heparin and induce angiogenesis. International Journal of Polymeric Materials and Polymeric Biomaterials 2016; 65(9): 466-476, https://doi.org/10.1080/00914037.2015. 1129959.

161. Huang Y.C., Yang Y.T. Effect of basic fibroblast growth factor released from chitosan-fucoidan nanoparticles on neurite extension. J Tissue Eng Regen Med 2016; 10(5): 418-427, https://doi.org/10.1002/term. 1752.

162. Zhang J., Li G., Gao S., Yao Y., Pang L., Li Y., Wang W., Zhao Q., Kong D., Li C. Monocyte chemoattractant protein-1 released from polycaprolactonelchitosan hybrid membrane to promote angiogenesis in vivo. Journal of Bioactive and Compatible Polymers 2014; 29(6): 572-588, https:/ldoi.org/10.1177/0883911514554146. 